\title{
PENGARUH BERBAGAI WARNA CAHAYA DAN Trichoderma sp. TERHADAP PERTUMBUHAN BIBIT KRISAN (Chrysanthemum sp.)
}

\author{
Disusun oleh : \\ Angga Adriana Imansyah**) \\ Dede Romansah*)
}

\begin{abstract}
Abstrak
Pemilihan varietas tanaman krisan yang diteliti didasarkan pada warna dasar krisan yaitu merah, putih dan kuning, Selain dari pemberian perlakuan perbedaan warna cahaya, untuk memaksimalkan pertumbuhan bunga krisan dapat di berikan perlakuan penambahan Tricoderma sp. untuk membantu percepatan pertumbuhan tanaman krisan tersebut. Penelitian ini bertujuan untuk mengetahui pengaruh beberapa warna cahaya ( merah, hijau, kuning, biru, dan putih) dan Trichoderma sp terhadap tinggi dan jumlah daun bunga krisan. Penelitian ini dilakukan secara eksperimental dengan pola Rancangan Acak Lengkap, terdiri dari dua faktor yaitu perlakuan warna cahaya dan konsentrasi Trichoderma sp. Hasil dari penelitian ini menunjukkan warna cahaya sangat berpengaruh terhadap pertumbuhan tinggi dan jumlah daun bunga krisan, sementara penambahan Trichoderma sp tidak berpengaruh nyata terhadap pertumbuhan bunga krisan hal tersebut di lihat dari hasil Uji ANOVA dengan taraf $\alpha 5 \%$. Dan dari penelitian ini dapat di simpulkan bahwa perlakuan warna cahaya kuning (W2) berpengaruh terhadap parameter pengamatan tinggi tanaman sementara perlakuan warna cahaya biru (W4) berpengaruh terhadap pertumbuhan jumlah daun.
\end{abstract}

Kata Kunci : Krisan, Cahaya, Trichoderma sp.

\section{Abstract}

The selection of chrysanthemum plant varieties studied is based on the basic colors of chrysanthemum, namely red, white and yellow. Beside of the of light color differences, to maximize the growth of chrysanthemum flowers can be given the addition of Tricoderma sp treatment to help accelerate the growth of chrysanthemum plants. This study aims to determine the effect of several colors of light (red, green, yellow, blue, and white) and Trichoderma sp on the height and number of chrysanthemum leaves. This research was conducted experimentally with a factorial randomized block design, consisting of two factors: light color treatment and concentration of Trichoderma sp. The results of this study indicate the color of light is very influential on the growth of height and number of chrysanthemum leaves, while the addition of Trichoderma sp has less significant effect on the growth of chrysanthemum. It is seen from the results of ANOVA Test with a level of 5\%. And from this study it can be concluded that the treatment of yellow light (W2) affects the parameters of observation of plant height while the treatment of blue light (W4) affects the growth of the number of leaves.

Keywords: Chrysanthemum, Light, Trichoderma sp.

*) Alumni Fakultas Sains Terapan UNSUR

**) Dosen Fakultas Sains Terapan UNSUR

\begin{tabular}{llr}
\multicolumn{2}{l}{ PENGARUH BERBAGAI } & WARNA CAHAYA \\
DAN Trichoderma & sp. & TERHADAP \\
PERTUMBUHAN & BIBIT & KRISAN \\
(Chrysanthemum sp.) & &
\end{tabular}




\section{PENDAHULUAN}

Krisan merupakan salah satu bunga tertua yang dibudidayakan manusia. Bunga krisan memegang peranan penting dalam budaya dan kehidupan manusia di negeri Cina dan Jepang, hampir selama 3000 tahun. Bunga krisan merupakan bunga yang mempunyai potensi sebagai bunga pot, bunga potong atau sebagai materi hiasan taman. sebagai tanaman hari pendek yang inisiasi dan perkembangan bunganya dikendalikan oleh panjang hari. Tanaman krisan membutuhkan cahaya lebih dari 13 jam sehari untuk tetap tumbuh secara vegetatif. Di daerah tropis seperti Indonesia kebutuhan tersebut tidak dapat dipenuhi oleh cahaya matahari yang lamanya rata-rata 12 jam sehari sehingga perlu ditambah dengan pencahayaan buatan dari lampu listrik yang biasanya dilakukan setelah matahari terbenam (Safriyudin. 2015).

Pemberian cahaya tambahan dengan berbagai warna dilakukan untuk memenuhi kebutuhan cahaya tanaman krisan agar dapat tumbuh optimal, warna cahaya yang sesuai akan diserap oleh tanaman dan digunakan untuk proses pertumbuhan secara lebih efisien. Pemilihan varietas tanaman krisan yang diteliti didasarkan pada warna dasar krisan yaitu merah, putih dan kuning (Ermawati et al. 2012)

Selain dari pemberian perlakuan perbedaan warna cahaya, untuk memaksimalkan pertumbuhan bunga krisan dapat di berrikan perlakuan penambahan Tricoderma sp untuk membantu percepatan pertumbuhan tanaman krisan tersebut.

Keuntungan menggunakan Trichoderma sp. yang berpotensi sebagai agen hayati adalah pertumbuhannya cepat, mudah dikulturkan dalam biakan maupun kondisi alami. Selain itu, beberapa jenis Trichoderma sp. dapat bertahan hidup dengan membentuk klamidospora pada kondisi yang tidak menguntungkan dan cukup tahan terhadap fungisida dan herbisida (Berlian et al., 2013).

Penelitian ini bertujuan untuk mengetahui pengaruh warna lampu dan penambahan trichoderma sp. Pada masing masing varietas tanaman krisan, sehingga menghasilkan pertumbuhan yang maksimal.

\section{METODE PENELITIAN}

\section{Waktu dan Tempat Penelitian}

Waktu pelakasanaan penelitian ini dilakukan selama 12 Hari mulai 25 Mei sampai 6 Juni 2019, bertempat di Taruna Tani Kacamata Agri Farm Cianjur (KAF), yang beralamat di Kp Serpong Desa Babakan Karet Kecamatan Cianjur.

\section{Alat dan Bahan}

Alat diantaranya : 1. Kotak kardus 2. Pot bunga 3. Lampu Warna LED 4. Kabel 5. Colokan 6. Handsprayer mini 6. Alat ukur. Bahan diantaranya : 1. Bibit krisan 2. Trichoderma sp. 3. Media tanam Media yang di gunakan adalah kombinasi campuran kotoran hewan dan skam bakar padi dengan perbandingan 1:1.

\section{Tahapan Penelitian}

1. Pembuatan kotak perlakuan

Kotak perlakuan dibuat dari bahan baku kardus. Bentuk kotak perlakuan yaitu persegi empat yang memiliki lima ruangan. Ukuran kotak perlakuan perruangan adalah tinggi 80 $\mathrm{cm}$ dan lebar $25 \mathrm{~cm}$. Setiap ruangan kotak perlakuan diberi lampu yang sesuai dengan penelitian.

2. Persiapan media

Media yang digunakan dalam penelitian ini adalah media sekam bakar dan kotoran hewan yang di campur dengan penambahan Trichoderma sp. dari masing-masing pot sesuai metode penelitian. Komposisi media perbandingannya 1 : 1 . Penelitian ini merujuk pada penelitian " Pertumbuhan Dan Hasil Caisin Pada Berbagai Warna Sungkup Plastik" (Sulistyaningsih, 2005).

\begin{tabular}{llr}
\multicolumn{2}{l}{ PENGARUH BERBAGAI } & WARNA CAHAYA \\
DAN Trichoderma & sp. & TERHADAP \\
PERTUMBUHAN & BIBIT & KRISAN \\
(Chrysanthemum sp.) & &
\end{tabular}

ANGGA ADRIANA IMANSYAH DEDE ROMANSAHI 
3. Perlakuan Cahaya dan Trichoderma sp. Masing-masing kotak diberikan cahaya lampu LED yang berbeda sesuai ketentuan penelitian, selanjutnya di berikan penambahan konsentrasi Tricodermasp masing-masing 5 gr, 10 gr, 15 gr dan kontrol pada setiap ulangan sesuai ketentuan penelitian. 4. Pengamatan dan pemeliharaan , Kegiatan pengamatan dilakukan setiap 3 hari dan pemeliharaan dilakukan Setiap hari di lihat perkembangan pertumbuhan benih, penyiraman di lakukan setiap dua kali perhari sesuai kebutuhan.

\section{Rancangan Percobaan}

Penelitian ini dilakukan secara eksperimental dengan pola Rancangan Acak Lengkap Faktorial. Penelitian ini terdiri dari dua faktor yaitu perlakuan warna cahaya dan konsentrasi Trichoderma sp. Faktor cahaya terdiri dari lima perlakuan yaitu, W1 : Perlakuan warna cahaya merah, W2 : Perlakuan warna cahaya kuning, W3 : Perlakuan warna cahaya hijau, W4 : Perlakuan warna cahaya biru, W5 : Perlakuan warna cahaya putih, Selanjutnya konsentrasi Trichoderma sp. terdiri dari empattaraf yaitu : T0 : Kontrol ( $0 \mathrm{gr} / \mathrm{kg}$ ), T1 : $5 \mathrm{gr} / \mathrm{kg}, \mathrm{T} 2: 10$ $\mathrm{gr} / \mathrm{kg}, \mathrm{T} 3: 15 \mathrm{gr} / \mathrm{kg}$. Sehingga kombinasi perlakuannya adalah sebagai berikut :

Tabel 1. Kombinasi perlakuan.

\begin{tabular}{llccccc}
\hline \multirow{2}{*}{\begin{tabular}{c} 
Krichoderma sp. (gr/kg) \\
\cline { 3 - 7 }
\end{tabular}} & $\begin{array}{c}\text { Merah } \\
\text { (W1) }\end{array}$ & $\begin{array}{c}\text { Kuning } \\
\text { (W2) }\end{array}$ & $\begin{array}{c}\text { Hijau } \\
\text { (W3) }\end{array}$ & $\begin{array}{c}\text { Biru } \\
\text { (W4) }\end{array}$ & $\begin{array}{c}\text { Putih } \\
\text { (W5) }\end{array}$ \\
\hline 0 & (T0) & T0W1 & T0W2 & T0W3 & T0W4 & T0W5 \\
5 & (T1) & T1W1 & T1W2 & T1W3 & T1W4 & T1W5 \\
10 & (T2) & T2W1 & T2W2 & T2W3 & T2W4 & T2W5 \\
15 & (T3) & T3W1 & T3W2 & T3W3 & T3W4 & T3W5 \\
\hline
\end{tabular}

Masing-masing perlakuan dilakukan pengulangan sebanyak tiga kali. Sehingga terdapat $5 \times 4 \times 3=60$ unit pengamatan Gambar 1).

Tata Letak Percobaan

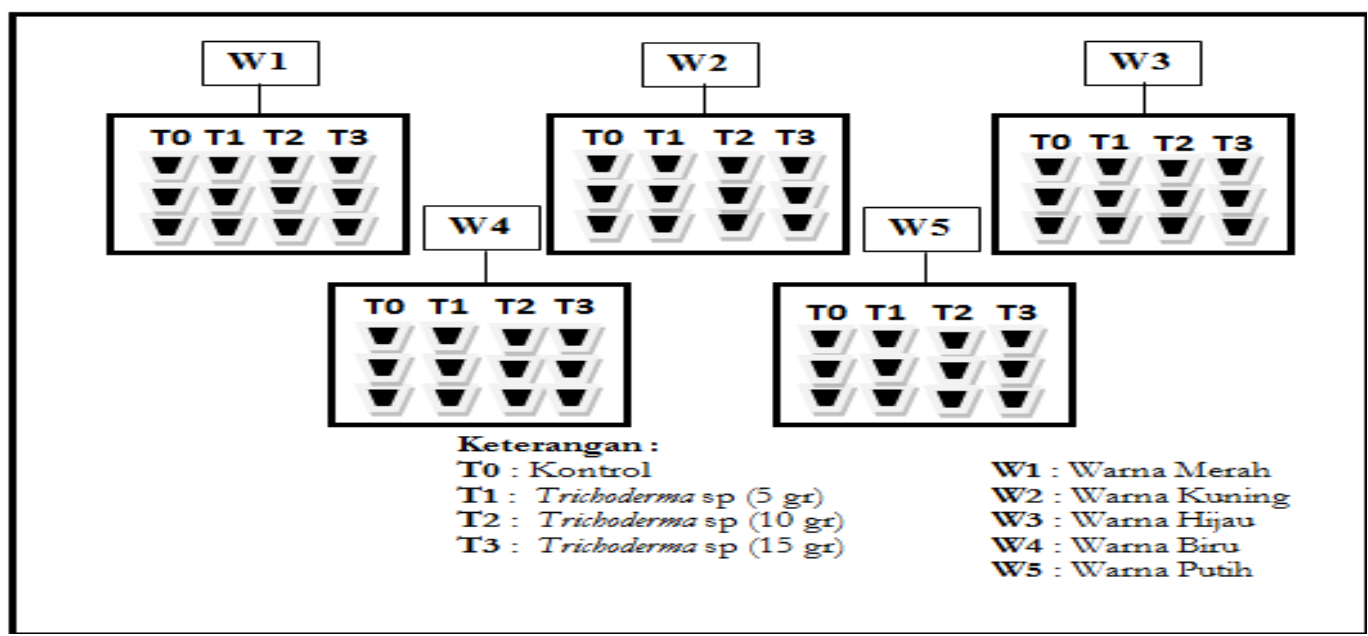

Gambar 1. Denah tata letak percobaan (Sumber : Dokumentasi Pribadi).

Perlakuan cahaya dimulai pukul 06.00 pagi sampai 06.00 sore dalam keadaan cahaya terang, dari pukul 06.00 sore sampai pukul 06.00 pagi dalam keadaan gelap, sementara penambahan konsentrasi Trichoderma sp. di aplikasikan

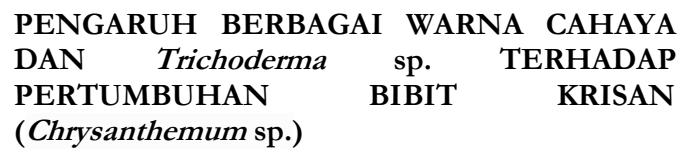

ANGGA ADRIANA IMANSYAH DEDE ROMANSAHI 
pada saat bersamaan dengan persiapan media tanam, masing-masing ulangan diberikan perlakuan secara berbeda seperti gambar denah tata letak di atas.

\section{Teknik Pengumpulan Data.}

Untuk menguji keabsahan kerangka pemikiran perlu pengamatan perubahan - perubahan sebagai berikut; 1. Tinggi bibit tanaman 2. Jumlah daun pada bibit

\section{Teknik Analisis data}

Data yang di peroleh kemudian di olah mengunakan ANOVA dengantaraf $\propto 5 \%$ dan di uji lanjut mengunakan Duncan Multipple Rank Test (DMRT). Aplikasi yang di gunakan $M s$ Excell dan SPSS.

\section{HASIL DAN PEMBAHASAN}

Parameter pertama dalam penelitian ini adalah mengukur tinggi bibit tanaman krisan pot setelah diberi perlakuan berbagai warna cahaya tambahan. Pengukuran tinggi tanaman dilakukan setiap tiga hari sekali, mulai satu minggu setelah tanam. Hasil analisis sidik ragam terhadap data tinggi tanaman krisan menunjukkan bahwa perlakuan cahaya berpengaruh terhadap tinggi krisan akan tetapi perlakuan Trichoderma sp. tidak berpengaruh terhadap tinggi bibit krisan, kecuali pada pengamatan ke-2 perlakuan Trichoderma sp. (T3 : $15 \mathrm{~g}$ ) berbeda nyata dengan T0 dan T1, akan tetapi tidak berbeda nyata dengan T2.

Hasil analisis sidik ragam juga menunjukkan tidak terdapat interaksi antara pemberian warna cahaya tambahan dengan konsentrasi Trichoderma sp. pada pengamatan 1, 3 dan 4, akan tetapi pada pengamatan ke 2 terjadi interaksi antara perlakuan warna (W2) dengan konsentrasi Trichoderma (T1) yaitu pada perlakuan W2T1 Seperti terlihat pada Tabel 2. dan Gambar 2.

Tabel 2. Pengaruh warna cahaya tambahan dan Trichoderma sp terhadap tinggi tanaman krisan.

\begin{tabular}{lcccc}
\hline \multirow{2}{*}{ Perlakuan } & \multicolumn{3}{c}{ Tinggi Tanaman $(\mathbf{C m})$} \\
\cline { 2 - 5 } Faktor 1 & Pengamatan 1 & Pengamatan 2 & Pengamatan3 & Pengamatan 4 \\
\hline W1 & $0,825 \mathrm{c}$ & $1,092 \mathrm{c}$ & $1,283 \mathrm{c}$ & $1,425 \mathrm{c}$ \\
W2 & $2,358 \mathrm{a}$ & $2,516 \mathrm{a}$ & $2,733 \mathrm{a}$ & $3,366 \mathrm{a}$ \\
W3 & $0,917 \mathrm{bc}$ & $1,225 \mathrm{c}$ & $1,366 \mathrm{c}$ & $1,583 \mathrm{c}$ \\
W4 & $1,200 \mathrm{bc}$ & $1,800 \mathrm{~b}$ & $2,025 \mathrm{~b}$ & $2,341 \mathrm{~b}$ \\
W5 & $0,908 \mathrm{bc}$ & $1,225 \mathrm{c}$ & $1,342 \mathrm{c}$ & $1,491 \mathrm{c}$ \\
\hline Faktor & & & & \\
\hline T0 & $1,313 \mathrm{c}$ & $1,446 \mathrm{c}$ & $1,653 \mathrm{c}$ & $2,020 \mathrm{c}$ \\
T1 & $1,093 \mathrm{c}$ & $1,653 \mathrm{c}$ & $1,540 \mathrm{c}$ & $2,220 \mathrm{c}$ \\
T2 & $1,346 \mathrm{c}$ & $1,546 \mathrm{c}$ & $1,813 \mathrm{bc}$ & $1,953 \mathrm{c}$ \\
T3 & $1,213 \mathrm{c}$ & $1,620 \mathrm{c}$ & $1,993 \mathrm{~b}$ & $1,973 \mathrm{c}$ \\
\hline Interaksi & $\mathrm{Ns}$ & $*$ & $\mathrm{Ns}$ & $\mathrm{Ns}$ \\
\hline
\end{tabular}

Keterangan: Angka-angka yang diikuti huruf berbeda nyata berdasarkan Uji Duncan Multiple Rank Test (DMRT) padat taraf $\alpha 5 \%$ atau P Value kurang dari 0,05\%. (W1 : Cahaya Merah, W2 : cahaya kuning, W3 : cahaya hijau, W4: cahaya biru, W5: cahaya putih). (To : konsentrasi Trichoderma sp 0 Gram, T1: 5 Gram, T2: 10 gram, T3: 15 gram. Ns $=$ Non Siugnificant, $*=$ Significant

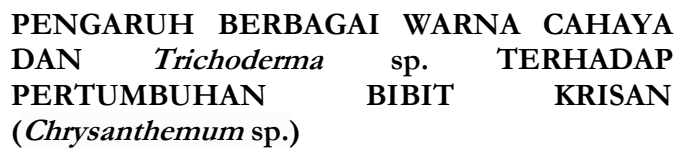




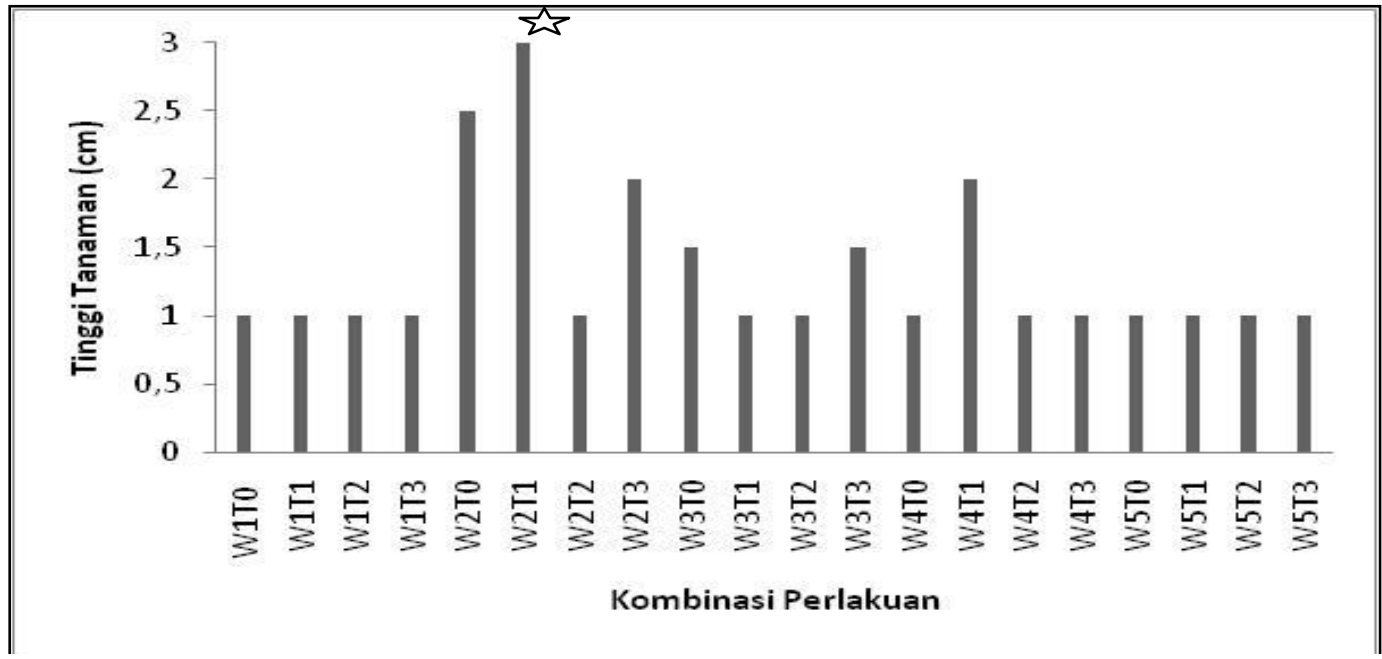

Gambar 2. Grafik interkasi pengaruh perlakuan Warna Cahaya dan Konsentrasi Trichoderma sp terhadap tinggi tanaman krisan. ((W1 : Cahaya Merah, W2 : cahaya kuning, W3 : cahaya hijau, W4: cahaya biru, W5: cahaya putih). (To : konsentrasi Trichoderma sp 0 Gram, T1: 5 Gram, T2: 10 gram, T3: 15 gram.)

Pengaruh Warna Cahaya Tambahan dan Konsentrasi Trichoderma sp. Terhadap Tinggi Tanaman Krisan
Pengaruh warna cahaya (w) terhadap pertumbuhan tinggi tanaman $(\mathrm{cm})$ bunga krisan umur 3-12 HST

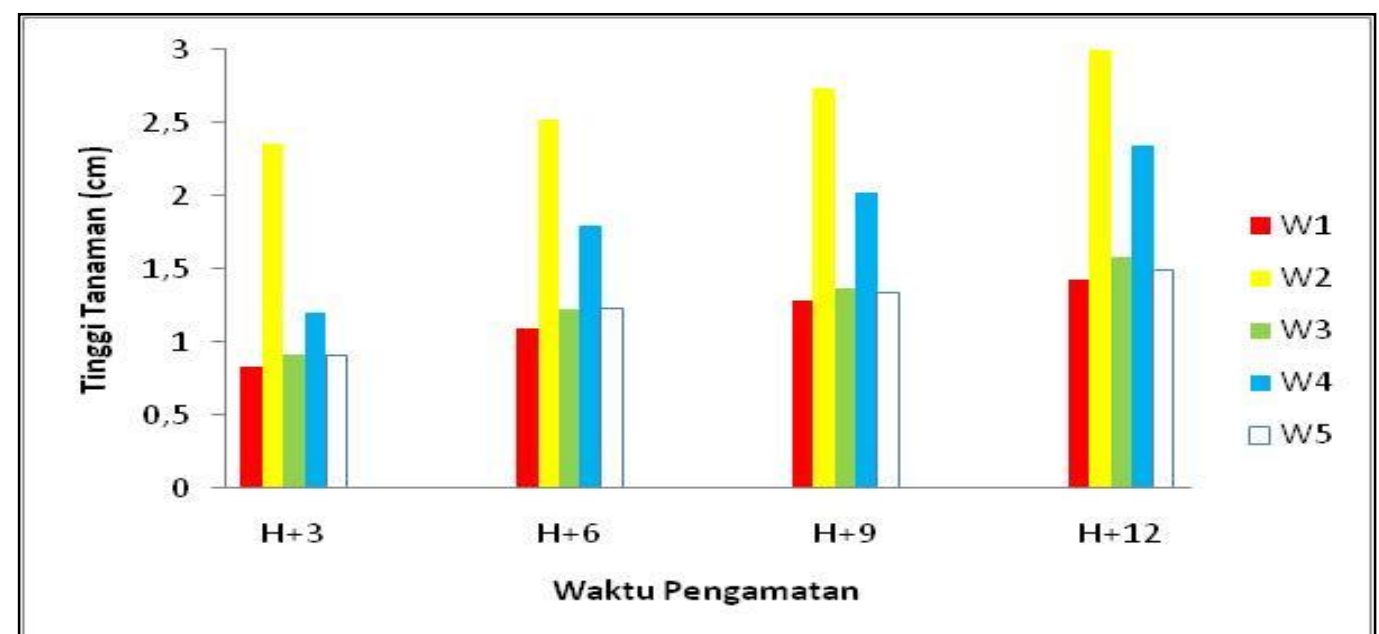

Gambar 3. Grafik pengaruh warna cahaya terhadap pertumbuhan tinggi tanaman (cm). ((W1 : Cahaya Merah, W2 : cahaya kuning, W3 : cahaya hijau, W4: cahaya biru, W5: cahaya putih).

Berdasarkan gambar 4.1.1 hari ke 3 HST menujukkan tinggi bibit krisan pada perlakuan cahaya kuning (W2) adalah $2,358 \mathrm{~cm}$, berbeda nyata dengan warna cahaya lainya $\mathrm{Hal}$ ini disebakan warna cahaya kuning dengan memiliki cahaya yang sangat terang dengan panjang gelombang berkisar antara $570-590 \mathrm{~nm}$, Sehingga mempengaruhi proses pertumbuhan tinggi tanaman. (Safriudin, 2012).

Seperti yang sudah di jelaskan pada teori, menurut (Soebagio, 2012) panjang gelombang yang bagus untuk pertumbuhan tanaman itu berkisar antara 400-700 nm. Sehingga disimpulkan bahwa cahaya lampu LED warna kuning sangat berpengaruh terhadap

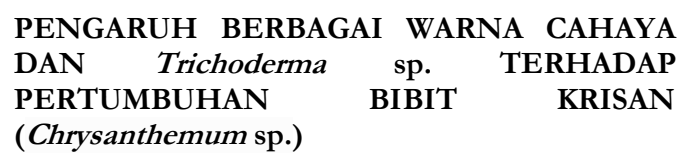


pertumbuhan tinggi tanaman, sedangkan penyerapan cblorophyl menghasilkan pertumbuhan yang kuat pada spektrum antara 390-510 nm. Spektrum 610-730 nm merupakan spektrum utama bagi proses photosintesa.

Hasil pengamatan terhadap cahaya tambahan lampu LED sangat berpengaruh pada pertumbuhan bunga krisan, namun tidak semua warna lampu memiliki panjang gelombang yang sesuai dengan proses fotosintesis bunga krisan, contohnya Lampu hijau dan putih kurang baik untuk proses fotosintesis karena tumbuhan yang berwarna hijau tidak bisa menyerap cahaya hijau, sedangkan lampu warna kuning dan biru bagus untuk pertumbuhan tanaman (lebar daun,tinggi batang) karena klorofil banyak menyerap cahaya kuning dan biru sehingga fotosintesis berjalan optimal dibanding dengan warna lampu lainnya. (Safriyudin, 2015)

Pada penelitian ini tidak terlihat pengaruh yang signifikan dari konsenttrasi Trichoderma terhadap pertambahan tinggi tanaman krisan. Hal ini diduga waktu pemberian perlakuan Trichoderma satu minggu sebelum tanam, belum mampu memberikan pengaruh yang signifikan. Trichoderma membutuhkan waktu untuk tumbuh dan berkembang sehingga mempunyai kemampuan sebagai pengurai, menghasilkan fitohorman dan berperan sebagai agens hayati.

Warna Cahaya Tambahan dan
Konsentrasi Trichoderma sp. Terhadap Jumlah Daun Bunga Krisan. Parameter kedua dalam penelitian ini adalah menghitung jumlah daun bibit tanaman krisan pot setelah diberi perlakuan berbagai warna cahaya tambahan. Penghitungan jumlah daun dilakukan setiap tiga hari sekali, mulai satu minggu setelah tanam.. Hasil analisis sidik ragam terhadap jumlah daun bibit tanaman krisan menunjukkan tidak terdapat interaksi antara pemberian warna cahaya tambahan dengan konsentrasi Trichoderma sp., akan tetapi pemberian warna cahaya tambahan berpengaruh terhadap jumlah daun bibit krisan (Tabel 4.2), hal ini dibuktikan dengan nilai $\mathrm{p}$ value $<0.05$ yaitu :

Tabel 3. Pengaruh warna cahaya tambahan dan trichoderma sp terhadap jumlah daun tanaman krisan.

\begin{tabular}{|c|c|c|c|c|}
\hline \multirow{2}{*}{$\begin{array}{c}\text { Perlakuan } \\
\text { Faktor } 1\end{array}$} & \multicolumn{4}{|c|}{ Jumlah Daun } \\
\hline & Pengamatan 1 & Pengamatan 2 & Pengamatan3 & Pengamatan 4 \\
\hline W1 & $1,166 \mathrm{c}$ & $1,250 \mathrm{c}$ & $1,916 \mathrm{c}$ & $2,083 \mathrm{bc}$ \\
\hline W2 & $2,583 a$ & $1,916 b$ & $3,333 b$ & $3,000 \mathrm{ab}$ \\
\hline W3 & $1,250 \mathrm{c}$ & $1,500 \mathrm{bc}$ & $2,083 c$ & $1,833 c$ \\
\hline W4 & $2,000 \mathrm{~b}$ & $4,166 \mathrm{a}$ & $3,000 \mathrm{~b}$ & $3,333 \mathrm{a}$ \\
\hline W5 & $1,500 \mathrm{c}$ & $1,583 \mathrm{bc}$ & $2,333 c$ & $2,583 \mathrm{bc}$ \\
\hline \multicolumn{5}{|l|}{ Faktor 2} \\
\hline T0 & $1,466 \mathrm{c}$ & $2,200 \mathrm{c}$ & $2,200 \mathrm{c}$ & $3,133 b$ \\
\hline $\mathrm{T} 1$ & $1,866 \mathrm{bc}$ & $1,866 \mathrm{c}$ & $2,866 \mathrm{~b}$ & $2,466 \mathrm{c}$ \\
\hline $\mathrm{T} 2$ & $1,466 \mathrm{c}$ & $2,200 \mathrm{c}$ & $2,800 \mathrm{~b}$ & $2,466 \mathrm{c}$ \\
\hline T3 & $2,000 \mathrm{~b}$ & $2,066 \mathrm{c}$ & $2,266 \mathrm{c}$ & $2,200 \mathrm{c}$ \\
\hline Interaksi & Ns & $\mathrm{Ns}$ & $\mathrm{Ns}$ & Ns \\
\hline
\end{tabular}

Keterangan:Angka-angka yang diikuti huruf berbeda nyata berdasarkan Uji Duncan Multiple Rank Test (DMRT) pada taraf $\propto 5 \%$ atau P Value kurang dari 0,05. (W1 : Cahaya Merah, W2 : cahaya kuning, W3 : cahaya hijau, W4: cahaya biru, W5: cahaya putih). (To : konsentrasi Trichoderma sp 0 Gram, T1: 5 Gram, T2: 10 gram, T3: 15 gram.

$\begin{array}{llr}\text { PENGARUH BERBAGAI } & \text { WARNA CAHAYA } \\ \text { DAN Trichoderma } & \text { sp. } & \text { TERHADAP } \\ \text { PERTUMBUHAN } & \text { BIBIT } & \text { KRISAN } \\ \text { (Chrysanthemum } \text { sp.) } & & \end{array}$

PENGARUH BERBAGAI WARNA CAHAYA (Chrysanthemum sp.) 
Hasil analisis beragam terhadap jumlah daun menunjukkan warna lampu LED berpengaruh nyata terhadap pengukuran jumlah daun krisan. Pada jumlah daun yang menggunakan lampu LED warna biru dan kuning memiliki pertumbuhan jumlah daun yang lebih cepat yaitu 16 daun dalam usia 12 Hari.

Pengaruh warna cahaya (W) terhadap pertumbuhan jumlah daun (helai) umur 3-12 HST

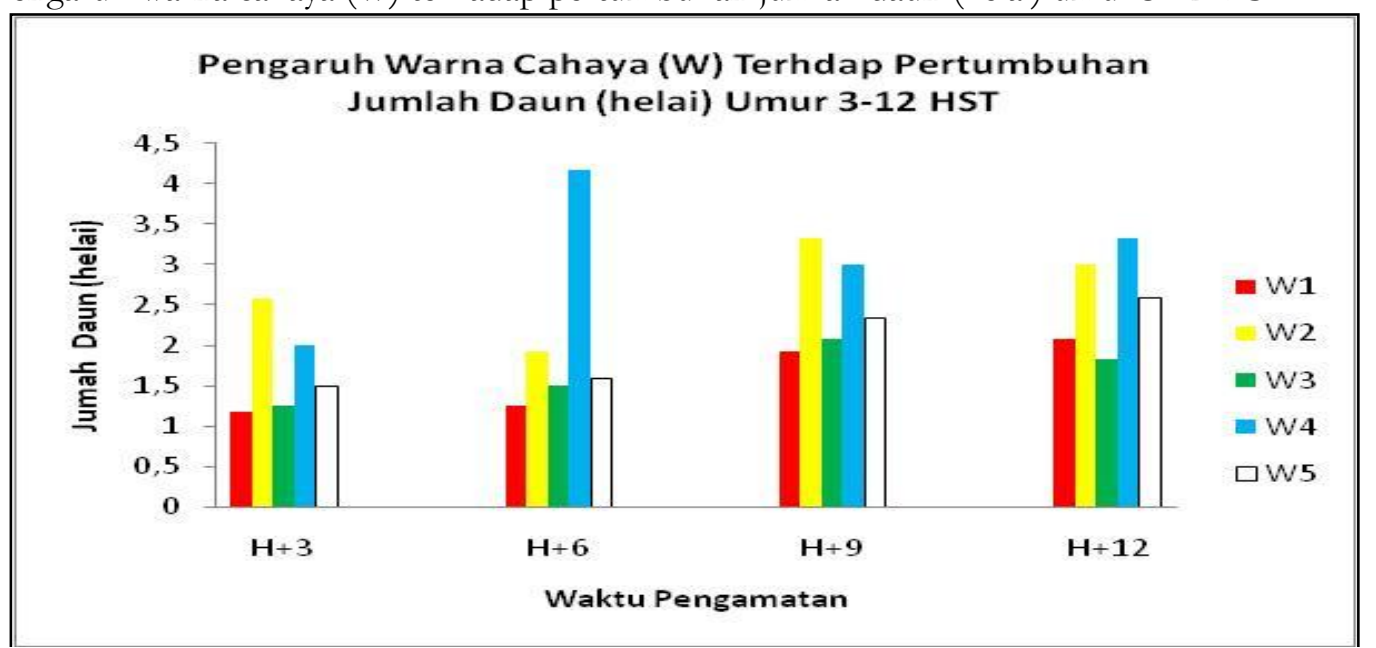

Gambar 4. Pengaruh warna cahaya (W) terhdap pertumbuhan jumlah daun (helai) umur 3-12 HST (W1 : Cahaya Merah, W2 : cahaya kuning, W3 : cahaya hijau, W4: cahaya biru, W5: cahaya putih).

Berbeda di hari pengamatan 3 HST, jumlah daun pada hari ke 6 menunjukan warna kuning (W2) justru mengalami penurunan angka yang pada hari ke 3 hasil uji Duncan dari 2,583 menurun sampai 1,916, namun warna biru (W4) justru menunjukan angka tertinggi dari angka 2 naik sampai 4,166 dengan di ikuti huruf a tunggal, hal tersebut artinya perlakuan warna biru menunjukkan peningkatan yang tinggi, dilihat dari panjang gelombang $450-500 \mathrm{~nm}$. Lampu warna biru bagus untuk pertumbuhan tanaman karena klorofil banyak menyerap cahaya biru sehingga fotosintesis berlangsung optimal. (Wiguna, 2015).Hal ini pun diduga peran fitokrom yang terdapat pada sel tanaman yang berfungsi sebagai reseptor cahaya (Fotoreseptor). Fitokrom dibagi menjadi dua yaitu Fitokrom merah (Pr) dan fitokrom merah jauh (Pfr) (Datta et al 2002). Pr memiliki puncak absorbsi pada panjang gelombang maksimal $660 \mathrm{~nm}$ dan Pfr maksimal panjang gelombang $730 \mathrm{~nm}$ (Sari, 2011). Hal tersebut menunjukkan bahwa warna biru dapat di respon sangat baik oleh tanaman melalui reseptor fitokrom merah (Pr) sehingga proses aktivasi giberelin pada tanaman sangat baik untuk multifikasi pemanjangan sel dan pembentukan jaringan selain itu fungsi lain dari Giberelin adalah Diferensiasi sel (Abidin, 1990; Salisbury dan Ross 1995)

$$
\text { Jumlah daun pada saat }
$$
pertumbuhan tanaman sangat berperan dalam menangkap cahaya khusus nya cahaya biru dan kuning yang berperan aktif pada proses pertumbuhan daun sebagai tempat berlangsungnya proses fotosintesis, selain daripada itu, perkembangan jumlah daun akan mempengaruhi perkembangan tanaman dan banyaknya daun akan semakin banyak cahaya di tangkap sehingga proses fotosintesis pun meningkat (Buntaro et al, 2014).

$\begin{array}{llr}\text { PENGARUH BERBAGAI } & \text { WARNA CAHAYA } \\ \text { DAN Trichoderma } & \text { sp. } & \text { TERHADAP } \\ \text { PERTUMBUHAN } & \text { BIBIT } & \text { KRISAN } \\ \text { (Chrysanthemum sp.) } & & \end{array}$

ANGGA ADRIANA IMANSYAH DEDE ROMANSAHI 


\section{PENUTUP}

\section{Kesimpulan}

1. Perlakuan berbagai warna cahaya berpengaruh nyata terhadap pertumbuhan tinggi dan jumlah daun pada tanaman bunga krisan pada umur tanam 3-12 HST ( Hari Setelah Tanam). Dilihat dari rata-rata signifikansi hasil ANOVA dengan taraf $\alpha 5 \%(0,005)$.

2. Perlakuan konsentrasi Trichoderma sp tidak berpengaruh nyata terhadap pertumbuhan tanaman krisan dilihat dari hasil ANOVA dengan taraf $\alpha 5 \%$.

3. Terdapat interaksi warna sahaya dan konsentrasi Trichoderma sp. Terhadap tinggi tanaman bunga krisan yaitu pada perlakuan W2T1.

\section{DAFTAR PUSTAKA}

Anas Mahirul Hakim, 2009. Asupan Nitrogen Dan Pupuk Organik Cair Terhadap Hasil Dan Kadar Vitamin C Kelopak Bunga Rosela. Surakarta, 4(5):28-40

Berlian, I dan B. Setyawan, dan H. Hadi. 2013. Mekanisme antagonisme (Tricoderma spp) Terhadap beberapa patogen tular tanah. Jurnal W arta Perkaretan 32 (2): 74 82.

Buntaro, Bagus, H., Rogomulyo dan Trisnowati, Sri. 2014. Pengaruh Takaran Pupuk Kandang Dan Intensitas Cahaya Terhadap Pertumbuhan Dan Hasil Temu Putih (curcuma zedoria L.). Vegetalik. 4(4):29-39

Campbell, N. A., J.B. Reece, and L. E. Mitchell. 2003. Biologi jilid 2. Terjemahan. Rahayu L, E. I. M. Adil, N Anita, Andri, W.F. Wibowo, dan W Manalu. Erlangga: Jakarta

Driyani, L.W. 2015. Pengaruh Pemberian Zat Pengatur Tumbuh (ZPT) Sintetik Auksin, Sitokinin Dan Giberelin Terhadap Kecepatan
Pertumbuhan Tanaman Sawi Pakcoy (Brassica Chinensis). Skripsi. Program Studi Pendidikan Biologi. Jurusan Pendidikan Matematika Dan Ilmu Pengetahuan Alam, Fakultas Keguruan Dan Ilmu Pendidikan, Universitas Sanata Dharma. Yogyakarta.

Effendi, K., and B. Marwoto. "Pola Night Break untuk Efisiensi Energi Listrik pada Usaha Krisan." Dalam: http://pustaka. bogor. net (2003).

Ermawati. D. 2012. Pengaruh warna cahaya tambahan terhadap pertumbuhan dan pembungaan tiga varietas tanaman krisan (chrysanthemum morifolium) potong. Jurnal Universitas Gajah Mada.

Fuad, 2017. Respon pertumbuhan padi Pandanwangi terhadap macammacam warna cahaya. Skripsi. Universitas Suryakancana Cianjur. Gusnawaty M. Taufik, L. Triana dan D Asniah. 2014. Karakterisasi Morfologis (Tricoderma spp) Indigenus Sulawesi Tenggara. Jurnal Agroteknos. 4(2): 87-93.

Handajaningsih, M., \& Wibisono, T. (2009). Pertumbuhan dan pembungaan krisan dengan pemberian abu janjang kelapa sawit sebagai sumber kalium. J. Akta Agrosia. 12(1), 8-14.

Syafriyudin, S., \& Ledhe, N. T. 2015. Analisis pertumbuhan tanaman krisan pada variabel warna cahaya lampu LED. Jurnal Teknologi, 8(1), 83-87.

Hayati, N. Q., \& Marwoto, B. 2018. Inovasi Teknologi Tanaman Krisan yang Dibutuhkan Pelaku Usaha (Technology Innovation of Chrysanthemum Needed by Stakeholders). Jurnal Hortikultura, 28(1), 147-162.

$\begin{array}{llr}\text { PENGARUH BERBAGAI } & \text { WARNA CAHAYA } \\ \text { DAN Trichoderma } & \text { sp. } & \text { TERHADAP } \\ \text { PERTUMBUHAN } & \text { BIBIT } & \text { KRISAN } \\ \text { (Chrysanthemum } \text { sp.) } & & \end{array}$

ANGGA ADRIANA IMANSYAH DEDE ROMANSAHI 
Puslitbang Hortikultura 2006. Budidaya krisan bunga potong, Puslitbang Hortikultura, Jakarta.

Rachmayati, D. A. 2014. Pengaruh Spektrum Warna Cahaya Terhadap Proses Pertumbuhan Tanaman Kacang Hijau. Jurnal Universitas syiah kuala.

Rahmah, S,Y. 2018. Potensi Bokasi Azzola sp. Dengan Bioaktivator Mol Rebung Terhadap Pertumbuhan Padi Pandanwangi Pada Fase Vegetatif. Skripsi. Universitas Suryakancana Cianjur Rukmana, R. dan A. E. Mulyana. 1997. Krisan. Kanisius, Yogyakarta.

Sach, R. M. and A. M. Konfranek. 1963. Comparative Cytohistological Studies on Inhibition And Promotion Of Stem Growth In Chrysanthemum Morifolium, Amer. Bot. 50:772-778. 